\title{
Potensi Tanaman Herbal Antidiabetes untuk Minuman Obat: Sebuah Literatur Review
}

\author{
Yulin Prisdiany ${ }^{1}$, Irma M. Puspitasari ${ }^{1,2}$, Norisca A. Putriana ${ }^{3}$, Mas Rizky A. A. Syamsunarno ${ }^{4}$ \\ ${ }^{1}$ Departemen Farmakologi dan Farmasi Klinik, Fakultas Farmasi, Universitas Padjadjaran, Sumedang, \\ Indonesia, ${ }^{2}$ Pusat Unggulan Iptek Perguruan Tinggi (PUI-PT) Inovasi Pelayanan Kefarmasian, \\ Universitas Padjadjaran, Sumedang, Indonesia, ${ }^{3}$ Departemen Farmasetika dan Teknologi Farmasi, \\ Fakultas Farmasi, Universitas Padjadjaran, Sumedang, Indonesia, ${ }^{4}$ Departemen Ilmu Kedokteran \\ Dasar, Fakultas Kedokteran, Universitas Padjadjaran, Sumedang, Indonesia
}

\begin{abstract}
Abstrak
Jumlah kasus dan prevalensi diabetes terus meningkat selama beberapa dekade terakhir. Pada tahun 2012, diabetes menyebabkan 1,5 juta kematian. Seiring berkembangnya pengetahuan, saat ini tanaman herbal lebih banyak digunakan sebagai bahan obat. Salah satu sediaan yang saat ini sedang banyak dikembangkan adalah sediaan minuman herbal. Minuman herbal kaya akan senyawa bioaktif alami. Bukti ilmiah menunjukkan bahwa senyawa bioaktif ini memberikan banyak efek biologis, seperti antioksidan, antibakteri, antidiabetes, dan lain-lain. Salah satu permasalahan yang berkaitan dengan penggunaan tanaman herbal adalah kurangnya penelitian atau pengujian secara ilmiah yang menunjukkan khasiat dari tanaman obat yang digunakan. Artikel ini memberikan gambaran secara ilmiah tentang tanaman herbal yang sudah terbukti memiliki khasiat antidiabetes yang dapat dimanfaatkan untuk pengembangan minuman obat herbal. Pencarian literatur melalui basis data elektronik PubMed pada bulan April 2020 dengan kata kunci "herbal tea" dan "antidiabetic" memperoleh total 30 artikel yang dapat ditelaah lebih lanjut. Sebanyak 12 artikel tentang uji in vitro, 16 artikel tentang uji in vivo, dan 2 artikel tentang uji klinik. Terdapat 35 jenis tanaman herbal di seluruh dunia yang terbukti dapat memberikan aktivitas antidiabetes. Bagian morfologi tanaman yang paling sering digunakan yaitu bagian daun. Mekanisme in vitro dari tanaman herbal dalam memberikan aktivitas antidiabetes adalah dengan menghambat aktivitas enzim $\alpha$-Amylase dan $\alpha$-Glucosidase. Pada uji in vivo dan uji klinik, semua tanaman herbal yang digunakan pada penelitian mempunyai aktivitas dalam membantu menurunkan kadar glukosa darah dan dapat dimanfaatkan sebagai minuman obat herbal.
\end{abstract}

Kata kunci: Antidiabetes, minuman herbal, tanaman herbal

\section{The Potential of Antidiabetic Herbal Plants for Medicinal Drinks: A Literature Review}

\begin{abstract}
Over the past few decades, an increase has occurred in the occurrence and prevalence of diabetes, with 1.5 million deaths recorded in 2012 alone. Currently, more herbal plants are being used as medicines including medicinal drinks, and these are rich in natural bioactive compounds. According to scientific evidence, these bioactive compounds provide many biological effects, for instance, antioxidant, antibacterial, and antidiabetic activities. However, one problem related to the use of herbal medicine is the inadequate research or scientific evidence of the plants' efficacy. This article, therefore, provides a scientific description of medicinal plants proven to exhibit antidiabetic properties and suitable for developing medicinal drinks. A literature search conducted across the PubMed electronic database in April 2020, using the keywords "herbal tea" and "antidiabetic" obtained a total of 30 articles, and of these publications, 12 were in vitro studies, 16 were pre-clinical studies, while 2 clinical trials. Across the world, 35 types of herbal plants have been proven to exhibit antidiabetic activity, with the leaves being the most commonly used part. The in vitro mechanism of herbal plants in exhibiting this antidiabetic activity is through inhibition of $\alpha$-Amylase and $\alpha$-Glucosidase enzyme activity. In addition, pre-clinical and clinical trials showed each plant in this study was able to reduce blood glucose levels and were suitable for developing medicinal drinks.
\end{abstract}

Keywords: Antidiabetic, herbal plants, medicinal drinks

Korespondensi: Yulin Prisdiany, Fakultas Farmasi, Universitas Padjadjaran, Sumedang, Jawa Barat 45363, Indonesia, email: yulin16001@mail.unpad.ac.id

Naskah diterima: 11 Mei 2020, Diterima untuk diterbitkan: 2 Juni 2021, Diterbitkan: 30 Juni 2021 


\section{Pendahuluan}

Diabetes adalah penyakit kronis yang terjadi akibat pankreas tidak dapat menghasilkan insulin (hormon yang mengatur gula darah atau glukosa) yang cukup, atau ketika tubuh tidak dapat menggunakan insulin yang dihasilkannya secara efektif. Diabetes adalah salah satu masalah kesehatan yang paling sering terjadi di masyarakat. Selama beberapa dekade terakhir jumlah kasus dan prevalensi diabetes terus meningkat. ${ }^{1}$ Pada tahun 2012, diabetes menyebabkan 1,5 juta kematian. Jumlah kematian bertambah sebanyak 2,2 juta, hal ini disebabkan penyakit diabetes juga dapat meningkatkan risiko terjadinya penyakit kardiovaskular dan penyakit lainnya. Sebanyak $43 \%$ dari total 3,7 juta kematian yang disebabkan penyakit diabetes terjadi sebelum usia 70 tahun. ${ }^{1}$ Prevalensi global diabetes melitus (DM) meningkat pada tingkat yang mengkhawatirkan dengan total jumlah sebanyak 381 juta yang dilaporkan terkena dampak pada tahun 2013. Diperkirakan 592 juta di antara populasi dunia akan mengidap penyakit diabetes pada tahun $2035 .^{2}$

Tanaman obat tradisional dapat menjadi sumber dari berbagai senyawa bioaktif, terutama senyawa fenolik. Mengonsumsi makanan/minuman yang kaya akan senyawa fenolik dapat menurunkan risiko beberapa penyakit tidak menular, seperti diabetes tipe 2 dan aterosklerosis. ${ }^{3}$ Ekstrak tumbuhan saat ini semakin banyak digunakan dalam produk makanan dan minuman dibandingkan produk berbahan kimia. ${ }^{4}$ Seiring dengan berkembangnya pengetahuan dan banyaknya penelitian mengenai hubungan antara produk makanan dan minuman kesehatan, ditambah dengan adanya inovasi pada bidang teknologi, telah dihasilkan produk baru, beberapa di antaranya memiliki potensi fungsional untuk mendapatkan manfaat kesehatan manusia. ${ }^{5}$

Secara umum, minuman herbal dibuat dari bahan-bahan alami dari bagian morfologi tanaman yang berbeda, yaitu daun, batang, akar, buah, kuncup, dan bunga. Minuman herbal adalah sumber yang kaya akan senyawa bioaktif alami seperti flavonoid, alkaloid, terpenoid, saponin, kumarin, asam fenolik, dan karotenoid. Bukti ilmiah menunjukkan bahwa senyawa bioaktif dapat memberikan banyak efek biologis, seperti antibakteri, antioksidan, antiinflamasi, anti alergi, antimutagenisitas, antikarsinogenisitas, dan efek antipenuaan. ${ }^{6}$ Minuman herbal yang disertai dengan uji sensori dan uji fitokimia yang memadai adalah cara ideal untuk menawarkan kepada konsumen yang membutuhkan manfaat dari minuman tersebut. ${ }^{7}$ Salah satu permasalahan yang berkaitan dengan penggunaan tanaman obat tradisional adalah kurangnya penelitian dan pengujian secara ilmiah khasiat dari tanaman obat yang digunakan. ${ }^{8}$ Penulisan artikel review ini bertujuan untuk memberikan gambaran secara ilmiah tentang tanaman herbal yang sudah terbukti memiliki khasiat antidiabetes sehingga dapat dimanfaatkan untuk pengembangan minuman kesehatan herbal.

\section{Metode}

Pencarian sumber literatur dilakukan pada bulan April 2020 melalui database PubMed dengan kata kunci "Antidiabetic" dan "Herbal Tea" dan detail pencarian sebagai berikut: (((“teas, herbal'"[MeSH Terms] OR ("teas"'All Fields] AND "herbal"[All Fields]) OR "herbal teas"[All Fields] OR ("herbal'[All Fields] AND "tea"[All Fields]) OR "herbal tea"[All Fields]) AND ("hypoglycemic agents"[Pharmacological Action] OR "hypoglycemic agents"[MeSH Terms] OR ("hypoglycemic"[All Fields] AND "agents"[All Fields]) OR "hypoglycemic agents"[All Fields] OR "antidiabetic"[All Fields])) AND ENGLISH[Language]) NOT ("review"[Publication Type] OR "review literature as topic"[MeSH Terms] OR "review" [All Fields]). 
Artikel yang didapat dari pencarian sumber literatur awal sebanyak 75 artikel. Artikel sebelum tahun 2010 dan bukan menggunakan bahasa Inggris dieksklusi. Dari 75 artikel, didapat 30 artikel mengenai studi minuman herbal antidiabetes. Bagan alir dari pencarian sumber literatur terdapat pada Gambar 1.

\section{Studi tentang Minuman Herbal Antidiabetes}

Tabel 1 menunjukkan 30 artikel mengenai studi tentang minuman herbal antidiabetes. Studi dilakukan di seluruh dunia pada tahun 2010 sampai 2020. Terdapat 35 jenis tanaman herbal yang digunakan yang tersebar diseluruh dunia. Bagian morfologi tanaman yang digunakan beragam, mulai dari akar, rimpang, daun, bunga, buah, korteks atau kulit batang, dan herba. Tipe studi yang dijelaskan terdiri dari studi in vitro, in vivo, dan klinik. Studi in vitro sebanyak 12 artikel, studi in vivo sebanyak 16 artikel, dan studi klinik sebanyak 2 artikel.

\section{Studi In Vitro Minuman Herbal Antidiabetes}

Tabel 2 menunjukkan 12 artikel mengenai studi in vitro minuman herbal antidiabetes. Studi in vitro (bahasa latin yang artinya "di dalam gelas") mengacu pada teknik melakukan prosedur yang diberikan di lingkungan yang terkendali di luar organisme hidup. Banyak percobaan dalam biologi seluler dilakukan di luar organisme atau sel. ${ }^{9}$

Berdasarkan literatur yang didapatkan, sebanyak 7 artikel menggunakan uji in vitro dengan metode penghambatan enzim $\alpha$-Glucosidase dan uji penghambatan enzim $\alpha$-Amylase. Alasan digunakan dua metode tersebut adalah karena DM ditandai oleh peningkatan abnormal kadar glukosa darah, yang diatur oleh $\alpha$-Glucosidase. Oleh karena itu, pengobatan DM sebagian besar difokuskan untuk mengendalikan fluktuasi gula darah setelah makan. Inhibitor $\alpha$-glukosidase dan $\alpha$-amilase dapat mengontrol kadar gula darah dengan menghambat aktivitas glikosidase

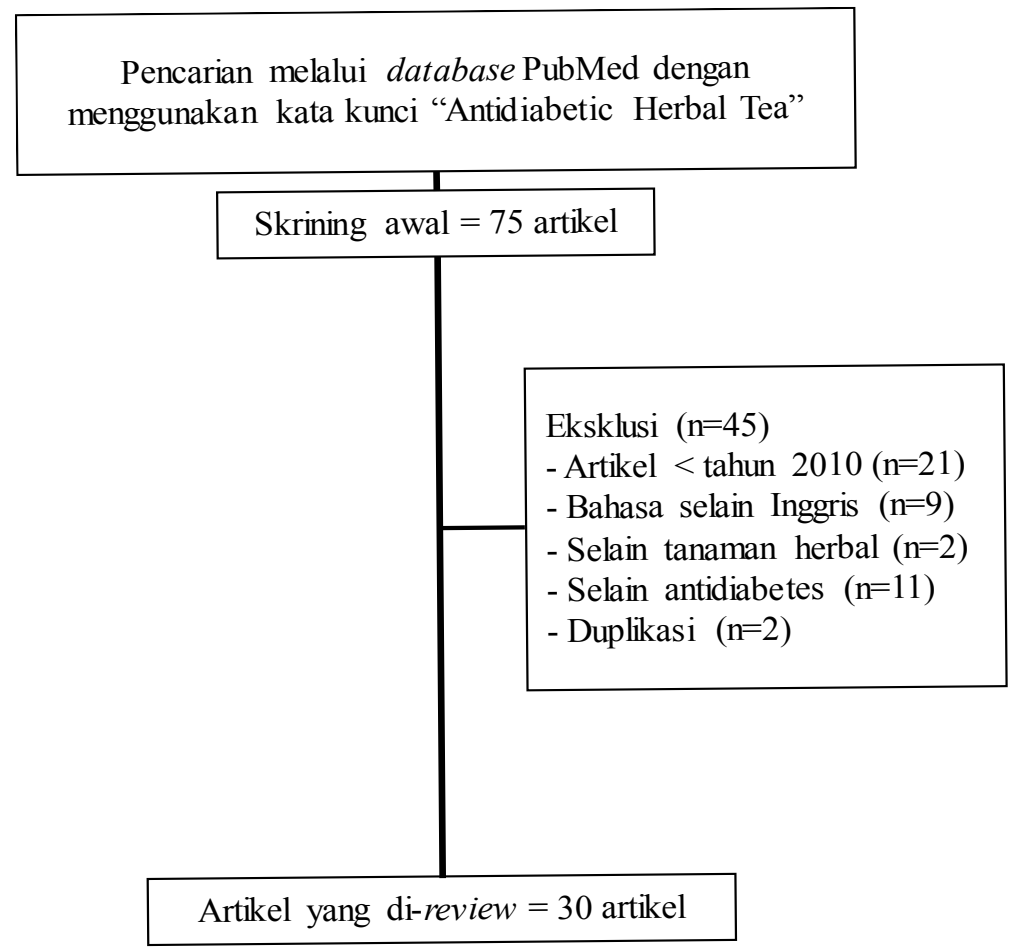

Gambar 1 Bagan Alur Pencarian Literatur 
Tabel 1 Daftar Artikel

\begin{tabular}{|c|c|c|c|c|c|c|c|}
\hline $\begin{array}{c}\text { No. } \\
\text { Artikel }\end{array}$ & Penulis & Tahun & Negara & Nama Tanaman & Nama Daerah & $\begin{array}{l}\text { Bagian Tanaman } \\
\text { yang Digunakan }\end{array}$ & Tipe Studi \\
\hline 1 & Meng Y, et al. ${ }^{11}$ & 2020 & Cina & Lithocarpus polystachyus & Lithocarpus polystachyus & Daun & In vitro \\
\hline 2 & Gremski, et al. ${ }^{12}$ & 2019 & Brazil & $\begin{array}{l}\text { Ilex paraguariensis. Melissa } \\
\text { officinalis, dan Cymbopogon } \\
\text { citratus }\end{array}$ & $\begin{array}{l}\text { Yerba mate, Lemon balm, } \\
\text { dan Sereh }\end{array}$ & Daun & In vitro \\
\hline 3 & Luo, et al. ${ }^{23}$ & 2019 & Cina & Psidium guajava, L. & Jambu biji & Daun & In vivo (Mencit) \\
\hline 4 & Ko, et al. ${ }^{41}$ & 2019 & Korea & Malva verticillata & Mallow & Herba & $\begin{array}{l}\text { In vivo (Larva } \\
\text { Zebrafish) }\end{array}$ \\
\hline 5 & Eruygur, et al. ${ }^{10}$ & 2019 & Turki & Morus alba dan Morus nigra & $\begin{array}{l}\text { Mulberry putih dan } \\
\text { Mulberry hitam }\end{array}$ & Daun & In vitro \\
\hline 6 & Jiang, et al. ${ }^{29}$ & 2018 & Cina & Coreopsis tinctoria & Coreopsis tinctoria & Bunga & In vivo (Tikus) \\
\hline 7 & Wang, et al..$^{17}$ & 2018 & Cina & Psidium guajava, L. & Jambu biji & Daun & In vitro \\
\hline 8 & Welch, et al. ${ }^{25}$ & 2018 & USA & Combretum micranthum & Kinkeliba & Daun & In vivo (Mencit) \\
\hline 9 & Pereira, et al. ${ }^{18}$ & 2018 & Portugal & $\begin{array}{l}\text { Artemisia campestris subsp. } \\
\text { maritima }\end{array}$ & Mugwort & Akar dan herba & In vitro \\
\hline 10 & Mayasari, et al. ${ }^{42}$ & 2018 & Indonesia & $\begin{array}{l}\text { Hibiscuss sabdariffa, Linn., } \\
\text { dan Stevia rebaudiana Bertoni }\end{array}$ & Rosela dan Stevia & Bunga dan daun & Klinik \\
\hline 11 & Liu, et al. ${ }^{26}$ & 2017 & USA & Gynostemma pentaphyllum & Jiaogulan & Daun & In vivo (Mencit) \\
\hline 12 & Rodriguez, et al. ${ }^{13}$ & 2017 & Turkey & $\begin{array}{l}\text { Matricaria chamomilla, } \\
\text { Camellia sinensis }\end{array}$ & Chamomile dan teh hijau & Bunga dan daun & In vitro \\
\hline 13 & Chen, et $a{ }^{24}$ & 2016 & Cina & Ampelopsis grossedentata & Moyeam & Daun dan batang & In vivo (Mencit) \\
\hline 14 & Lee, et al. ${ }^{30}$ & 2015 & Korea & Camellia sinensis L. & Teh hijau & Daun & In vivo (Tikus) \\
\hline 15 & Ma, et al..$^{14}$ & 2015 & Cina & Edgeworthia gardneri & Edgeworthia gardneri & Bunga & In Vitro \\
\hline 16 & Bernardo, et al. ${ }^{43}$ & 2015 & Portugal & Cinnamomum burmannii & Kayu manis & Korteks/kulit kayu & Klinik \\
\hline 17 & Kamakura, et al. ${ }^{27}$ & 2015 & Jepang & Aspalathus linearis & Rooibos/Semak merak & Daun & In vivo (Mencit) \\
\hline 18 & Khan, et al. ${ }^{31}$ & 2014 & Pakistan & Matricaria chamomilla & Chamomile & Bunga & In vivo (Tikus) \\
\hline 19 & Oboh, et al. ${ }^{15}$ & 2014 & Nigeria & $\begin{array}{l}\text { Green tea, black tea, white } \\
\text { tea, puerariae, ophiopogonis, } \\
\text { Crateagus oxcanthus, } \\
\text { Ipomoea batatas, dan } \\
\text { Solomon seal }\end{array}$ & $\begin{array}{l}\text { Teh hijau, teh hitam, teh } \\
\text { putih, kudzu/ krandang, } \\
\text { Akar mai dong, Hawthorn } \\
\text { berry, ubi, dan YuZhu }\end{array}$ & $\begin{array}{l}\text { Daun, rimpang, dan } \\
\text { akar }\end{array}$ & In vitro \\
\hline
\end{tabular}




\section{Tabel 1 Daftar Artikel (Tabel Lanjutan)}

\begin{tabular}{|c|c|c|c|c|c|c|c|}
\hline $\begin{array}{c}\text { No. } \\
\text { Artikel }\end{array}$ & Penulis & Tahun & Negara & Nama Tanaman & Nama Daerah & $\begin{array}{l}\text { Bagian Tanaman } \\
\text { yang Digunakan }\end{array}$ & Tipe Studi \\
\hline 20 & Dludla, et al. ${ }^{32}$ & 2014 & $\begin{array}{l}\text { Afrika } \\
\text { Selatan }\end{array}$ & Aspalathus linearis & Rooibos/Semak merak & Daun & In vivo (Tikus) \\
\hline 21 & Dalar, et al. ${ }^{16}$ & 2014 & Turki & Eryngium bornmuelleri & Culantro & Daun & In vitro \\
\hline 22 & Wang, et al..$^{34}$ & 2013 & Cina & Cyclocarya paliurus & Bidara & Daun & In vivo (Tikus) \\
\hline 23 & Oliveira, et al..$^{19}$ & 2013 & Portugal & Spergularia rubra & Red sandspurry & Herba & In vitro \\
\hline 24 & Chen, et al..$^{20}$ & 2013 & Cina & Microcos paniculata L. & Microcos paniculata L. & Daun & In vitro \\
\hline 25 & Jung, et al. ${ }^{28}$ & 2012 & Korea & Diospyros kaki & Persimmon/kesemek & Daun & In vivo (Mencit) \\
\hline 26 & Muller, et al. ${ }^{33}$ & 2012 & $\begin{array}{l}\text { Afrika } \\
\text { Selatan }\end{array}$ & Aspalathus linearis & Rooibos/Semak merak & Daun & In vivo (Tikus) \\
\hline 27 & Nyirenda, et al. ${ }^{21}$ & 2012 & $\begin{array}{l}\text { Afrika } \\
\text { Selatan }\end{array}$ & Fadogia ancylantha & Makoni/kahitutan & Daun & In vitro \\
\hline 28 & Wainstein, et al. ${ }^{35}$ & 2012 & Israel & Olea europaea L. & Zaitun & Daun & In vivo (Tikus) \\
\hline 29 & $\begin{array}{l}\text { Naowaboot, et } \\
\text { al. }^{36}\end{array}$ & 2012 & Thailand & Morus alba L. & Mulberry putih & Daun & In vivo (Tikus) \\
\hline 30 & Azevedo, et al. ${ }^{37}$ & 2011 & Portugal & Salvia fruticosa & Sage & Herba & In vivo (Tikus) \\
\hline
\end{tabular}

Tabel 2 Studi In Vitro Minuman Herbal Antidiabetes

\begin{tabular}{|c|c|c|c|c|c|c|}
\hline $\begin{array}{c}\text { No. } \\
\text { Artikel }\end{array}$ & Nama Tanaman & $\begin{array}{l}\text { Bagian yang } \\
\text { Digunakan }\end{array}$ & Ekstraksi & Dosis & Efek/Hasil & Mekanisme \\
\hline 1 & $\begin{array}{l}\text { Lithocarpus } \\
\text { polystachyus }\end{array}$ & Daun & $\begin{array}{l}0,2 \mathrm{~g} \text { serbuk dilarutkan dengan } \\
8 \mathrm{~mL} \text { aqueous methanol } 90 \%\end{array}$ & $1,25 \mathrm{mg} / \mathrm{mL}$ & $\begin{array}{l}\text { Antidiabetes dan } \\
\text { antioksidan }\end{array}$ & $\begin{array}{l}\text { Menghambat } \alpha \text {-Glucosidase } \\
>88,1 \% \text { dan menghambat } \\
\text { Protein Tyrosine Phosphatase- } \\
1 b(\mathrm{PTP} 1 \mathrm{~B})>84,3 \%\end{array}$ \\
\hline 2 & $\begin{array}{l}\text { Ilex paraguariensis, } \\
\text { Melissa officinalis, } \\
\text { dan Cymbopogon } \\
\text { citratus }\end{array}$ & Daun & $\begin{array}{l}3 \text { g sampel dilarutkan dalam } \\
100 \mathrm{~mL} \text { air suling pada suhu } \\
80 \pm 2^{\circ} \mathrm{C} \text { dalam wadah selama } \\
10 \text { menit }\end{array}$ & $\begin{array}{l}20 \mathrm{mg} / \mathrm{mL} \text { dan } \\
500 \mu \mathrm{g} / \mathrm{mL}\end{array}$ & $\begin{array}{l}\text { Antidiabetes, } \\
\text { antihipertensi, dan } \\
\text { antioksidan }\end{array}$ & $\begin{array}{l}\text { Menghambat aktivitas enzim } \\
\alpha \text {-Amylase sebesar } 40 \% \text { dan } \\
\alpha \text {-Glucosidase sebesar } 71,3 \%\end{array}$ \\
\hline 5 & $\begin{array}{l}\text { Morus alba dan } \\
\text { Morus nigra }\end{array}$ & Daun & $\begin{array}{l}\text { Sampel dimaserasi dengan ethanol } \\
80 \%(1 \mathrm{~L} \times 3)\end{array}$ & $2000 \mu \mathrm{g} / \mathrm{mL}$ & $\begin{array}{l}\text { Antidiabetes dan } \\
\text { antioksidan }\end{array}$ & $\begin{array}{l}\text { Menghambat aktivitas enzim } \\
\alpha \text {-Amylase dan } \alpha \text {-Glucosidase }\end{array}$ \\
\hline 7 & Psidium guajava, L. & Daun & $\begin{array}{l}\text { Sampel direndam dengan air pada } \\
\text { suhu } 121^{\circ} \mathrm{C} \text { selama } 15 \text { menit }\end{array}$ & $30 \mu \mathrm{g} / \mathrm{mL}$ & $\begin{array}{l}\text { Antidiabetes dan } \\
\text { antioksidan }\end{array}$ & $\begin{array}{l}\text { Menghambat aktivitas } \\
\alpha \text {-Glucosidase }\end{array}$ \\
\hline
\end{tabular}




\section{Tabel 2 Studi In Vitro Minuman Herbal Antidiabetes (Tabel Lanjutan)}

\begin{tabular}{|c|c|c|c|c|c|c|}
\hline $\begin{array}{l}\text { No. } \\
\text { Artikel }\end{array}$ & Nama Tanaman & $\begin{array}{l}\text { Bagian yang } \\
\text { Digunakan }\end{array}$ & Ekstraksi & Dosis & Efek/Hasil & Mekanisme \\
\hline 9 & $\begin{array}{l}\text { Artemisia } \\
\text { campestris subsp. } \\
\text { maritima }\end{array}$ & Akar dan herba & $\begin{array}{l}1 \text { g sampel dididihkan dalam air } \\
\text { selama } 5 \text { menit }\end{array}$ & $0,89-1,13 \mathrm{mg} / \mathrm{mL}$ & $\begin{array}{l}\text { Antidiabetes dan } \\
\text { antioksidan }\end{array}$ & $\begin{array}{l}\text { Menghambat aktivitas } \\
\alpha \text {-Glucosidase }\end{array}$ \\
\hline 12 & $\begin{array}{l}\text { Matricaria } \\
\text { chamomilla, } \\
\text { Camellia sinensis }\end{array}$ & $\begin{array}{l}\text { Bunga dan } \\
\text { daun }\end{array}$ & $\begin{array}{l}\text { Chamomile diekstraksi dengan } \\
\text { etanol } 60 \% \text {, teh hijau diekstraksi } \\
\text { dengan air }\end{array}$ & 2 dan $3 \mathrm{~g} / \mathrm{mL}$ & Antidiabetes & $\begin{array}{l}\text { Menghambat aktivitas enzim } \\
\alpha \text {-Amylase dan } \alpha \text {-Glucosidase }\end{array}$ \\
\hline 15 & $\begin{array}{l}\text { Edgeworthia } \\
\text { gardneri }\end{array}$ & Bunga & $\begin{array}{l}12 \mathrm{~kg} \text { sampel diekstraksi } 3 \text { kali } \\
\text { selama } 7 \text { hari dengan } \\
40 \mathrm{~L} \mathrm{MeOH} \text { pada suhu ruang }\end{array}$ & $18,7 \mu \mathrm{g} / \mathrm{mL}$ & Antidiabetes & $\begin{array}{l}\text { Menghambat aktivitas enzim } \\
\alpha \text {-Amylase dan } \alpha \text {-Glucosidase }\end{array}$ \\
\hline 19 & $\begin{array}{l}\text { Green tea, } \\
\text { black tea,white } \\
\text { tea, puerariae, } \\
\text { ophiopogonis, } \\
\text { Crateagus } \\
\text { oxcanthus, } \\
\text { Ipomoea batatas, } \\
\text { dan Solomon seal }\end{array}$ & $\begin{array}{l}\text { Daun, rimpang, } \\
\text { dan akar }\end{array}$ & $\begin{array}{l}\text { 1g dari tiap sampel (tea bag) } \\
\text { diekstrak dengan } 100 \mathrm{~mL} \\
\text { air panas }\end{array}$ & $50-200 \mathrm{mg} / \mathrm{mL}$ & $\begin{array}{l}\text { Antidiabetes dan } \\
\text { antioksidan }\end{array}$ & $\begin{array}{l}\text { Menghambat aktivitas enzim } \\
\text { Pancreatic- } \alpha \text {-Amylase dan } \\
\text { Intestinal- } \alpha \text {-Glucosidase }\end{array}$ \\
\hline 21 & $\begin{array}{l}\text { Eryngium } \\
\text { bornmuelleri }\end{array}$ & Daun & $\begin{array}{l}\text { Sampel dicampur dengan acidified } \\
\text { ethanol }\left(80 \% \text { etanol, } 19 \% \mathrm{H}_{2} \mathrm{O}\right. \\
\text { and } 1 \% \text { asam trifluoroacetic } 0,1 \% \text {, } \\
\text { v/v/v), dikocok } 2 \text { jam pada } \\
\text { suhu ruang }\left(22^{\circ} \mathrm{C}\right)\end{array}$ & $8.3 \mathrm{mg} / \mathrm{mL}$ & $\begin{array}{l}\text { Antidiabetes dan } \\
\text { antioksidan }\end{array}$ & $\begin{array}{l}\text { Menghambat aktivitas enzim } \\
\alpha \text {-Amylase dan } \alpha \text {-Glucosidase }\end{array}$ \\
\hline 23 & Spergularia rubra & Herba & $\begin{array}{l}\text { Sampel diekstraksi dengan } \\
\text { campuran ethanol:air }(1: 1)\end{array}$ & $1 \mathrm{~g} / 100 \mathrm{~mL}$ & Antidiabetes & $\begin{array}{l}\text { Menghambat aktivitas enzim } \\
\alpha \text {-Glucosidase }\end{array}$ \\
\hline 24 & $\begin{array}{l}\text { Microcos paniculata } \\
\text { L. }\end{array}$ & Daun & $\begin{array}{l}\text { Sampel direflux pada suhu } 90^{\circ} \mathrm{C} \\
\text { selama } 45 \text { menit dengan } 70 \% \\
\text { metanol dalam rasio } 1 / 25 \mathrm{~g} / \mathrm{mL} \\
(\mathrm{w} / \mathrm{v})\end{array}$ & $61,3 \mu \mathrm{g} / \mathrm{mL}$ & Antidiabetes & $\begin{array}{l}\text { Menghambat aktivitas enzim } \\
\alpha \text {-Glucosidase }\end{array}$ \\
\hline 25 & Fadogia ancylantha & Daun & $\begin{array}{l}50 \text { g sampel ditambah } 2 \mathrm{~L} \\
\text { metanol:diklorometan }(1: 1) \text {, } \\
\text { diaduk dan disimpan selama } \\
1 \text { malam di suhu ruang }\end{array}$ & $12,5 \mu \mathrm{g} / \mathrm{mL}$ & $\begin{array}{l}\text { Antidiabetes, } \\
\text { antioksidan, dan } \\
\text { antimikroba }\end{array}$ & $\begin{array}{l}\text { Memperbaiki/meningkatkan } \\
\text { penyerapan glukosa }\end{array}$ \\
\hline
\end{tabular}


secara kompetitif dan mencegah penguraian gula yang cepat. $^{10}$ Pengujian dilakukan dengan cara sampel ditambahkan dimetil sulfoksidan dan ditambahkan p-nitrofenil$\alpha$-D-glukopiranosida agar terjadi reaksi enzimatis kemudian diinkubasi, dan dilihat absorbansinya pada panjang gelombang $405 \mathrm{~nm}$ untuk $\alpha$-Glucosidase dan $540 \mathrm{~nm}$ untuk $\alpha$-Amylase. Selanjutnya, untuk kontrol positif digunakan acarbose yang merupakan salah satu obat inhibitor $\alpha$-Glucosidase.

Berdasarkan hasil dari beberapa penelitian dengan studi in vitro, aktivitas inhibisi $\alpha$-Glucosidase dan $\alpha$-Amylase terdapat pada tanaman Lithocarpus polystachyus dari Cina. Tanaman ini telah terbukti menunjukkan penghambatan enzim $\alpha$-Glucosidase lebih dari $88,1 \%$ dan penghambatan protein tyrosine phosphatase 1B (PTP1B) lebih dari $84,3 \% .{ }^{11}$ Selanjutnya, terdapat tanaman Ilex paraguariensis, lemon balm, dan sereh yang terbukti menunjukkan penghambatan enzim $\alpha$-Glucosidase sebesar $71,3 \%$ dan $\alpha$-Amylase sebesar $40 \% .^{12}$ Hasil yang didapat dari aktivitas tanaman herbal tersebut lebih tinggi dibandingkan dengan acarbose. Selain itu terdapat tanaman mulberry (M. alba dan $M$. nigra) yang juga memiliki aktivitas inhibisi enzim $\alpha$-Glucosidase dan $\alpha$-Amylase namun masih lebih rendah apabila dibandingkan dengan acarbose. ${ }^{10}$ Tanaman lainnya yang menunjukkan aktivitas inhibisi $\alpha$-Glucosidase dan $\alpha$-Amylase yaitu bunga chamomile, ${ }^{13}$ bunga Edgeworthia gardneri, ${ }^{14}$ teh hijau, teh hitam (black tea), teh putih (white tea) ${ }^{15}$ dan culantro (Eryngium bornmuelleri). ${ }^{16}$

Sebanyak 4 artikel yang membahas tentang tanaman herbal yang hanya menunjukkan aktivitas inhibisi $\alpha$-Glucosidase yaitu tanaman daun jambu biji, ${ }^{17}$ mugwort, ${ }^{18}$ Spergularia rubra, ${ }^{19}$ dan Microcos paniculate, L. ${ }^{20}$ Tanaman Fadogia ancylantha telah terbukti berpotensi $10 \%$ lebih baik dalam penyerapan glukosa dibandingkan metformin (digunakan sebagai kontrol positif). Ekstrak organik tanaman tersebut mampu memperbaiki atau meningkatkan penyerapan glukosa sebesar $172,29 \pm 0,32 \%{ }^{21}$

\section{Studi In Vivo Minuman Herbal Antidiabetes}

Tabel 3 menunjukkan 16 artikel mengenai studi in vivo minuman herbal antidiabetes. Studi in vivo adalah studi yang menggunakan hewan percobaan untuk mempelajari potensi obat terapeutik. Studi in vivo merupakan langkah penting sebelum dilakukannya uji klinik. ${ }^{22}$ Berdasarkan hasil studi yang didapat, hewan uji yang digunakan dalam uji in vivo yaitu mencit ( 6 artikel), tikus ( 9 artikel), dan juga terdapat teknologi baru yaitu dengan menggunakan larva Zebrafish (1 artikel).

Dari total 6 artikel yang menggunakan hewan uji mencit, diketahui sebanyak 2 artikel menjelaskan bahwa mencit diinduksi dengan menggunakan streptozotocin (STZ) dan diet tinggi lemak (HFD) agar hewan uji tersebut diabetes. Hasil menunjukkan bahwa pada tanaman daun jambu biji terbukti memiliki aktivitas antidiabetes dengan mekanisme dapat menurunkan kadar glukosa darah puasa, kolesterol total, trigliserida, glycated serum protein (GSP), kreatinin, Malondialdehid (MDA). ${ }^{23}$ Tanaman Ampelopsis grossedentata terbukti dapat menurunkan kadar glukosa darah postpandrial. ${ }^{24}$ Selanjutnya, sebanyak 2 artikel menjelaskan mencit diinduksi dengan menggunakan larutan glukosa, dan dengan kelompok kontrol menggunakan metformin. Hasil studi tersebut menunjukkan bahwa ekstrak Combretum micranthum dapat menekan kenaikan kadar glukosa dari $336 \pm 50 \mathrm{mg} / \mathrm{dL}$ pada menit ke-40 menjadi $315 \pm 62 \mathrm{mg} / \mathrm{dL}$ pada menit ke-80. ${ }^{25}$ Pada tanaman Gynostemma pentaphyllum, terbukti dapat menurunkan resistensi insulin. ${ }^{26}$ Selanjutnya, digunakan metode pengaturan diet makanan pada mencit selama 1 minggu. Kemudian dibagi menjadi dua kelompok, yaitu kelompok kontrol dan perlakuan. Pada mencit kelompok perlakuan 
Tabel 3 Studi In Vivo Minuman Herbal Antidiabetes

\begin{tabular}{|c|c|c|c|c|c|c|c|}
\hline $\begin{array}{l}\text { No. } \\
\text { Artikel }\end{array}$ & $\begin{array}{c}\text { Nama } \\
\text { Tanaman }\end{array}$ & $\begin{array}{c}\text { Bagian yang } \\
\text { Digunakan }\end{array}$ & Ekstraksi & Dosis & Hewan Uji & Efek/ Hasil & Mekanisme \\
\hline 3 & $\begin{array}{l}\text { Psidium } \\
\text { guajava, L. }\end{array}$ & Daun & $\begin{array}{l}10 \text { g sampel kering } \\
\text { dilarutkan dalam } \\
40 \text { mL ethanol } 95 \%\end{array}$ & $\begin{array}{l}10 \mathrm{mg} / \mathrm{kg} \text { per hari } \\
\text { selama } 4 \text { minggu }\end{array}$ & Mencit & $\begin{array}{l}\text { Antidiabetes dan } \\
\text { antioksidan }\end{array}$ & $\begin{array}{l}\text { Menurunkan kadar glukosa } \\
\text { darah puasa, kolesterol total, } \\
\text { trigliserida, GSP, kreatinin, } \\
\text { MDA }\end{array}$ \\
\hline 4 & $\begin{array}{l}\text { Malva } \\
\text { verticillata }\end{array}$ & Herba & $\begin{array}{l}3,1 \mathrm{~kg} \text { sampel } \\
\text { diekstraksi dengan } \\
\text { MeOH } 80 \%(54 \mathrm{Lx} 5) \\
\text { pada suhu ruang } \\
\text { selama } 24 \text { jam }\end{array}$ & $\begin{array}{l}1 \mu \mathrm{g} / \mathrm{mL} 1 \mathrm{kali} \\
\text { selama } 12 \text { jam }\end{array}$ & $\begin{array}{l}\text { Larva } \\
\text { Zebrafish }\end{array}$ & Antidiabetes & $\begin{array}{l}\text { Memulihkan kerusakan } \\
\text { Alloxan pada sel islet } \\
\text { pankreas }\end{array}$ \\
\hline 6 & $\begin{array}{l}\text { Coreopsis } \\
\text { tinctoria }\end{array}$ & Bunga & $\begin{array}{l}250 \mathrm{mg}, 500 \mathrm{mg} \text {, } \\
\text { dan } 1000 \mathrm{mg} \text { sampel } \\
\text { direndam selama } 10 \\
\text { menit dalam } 1 \mathrm{~L} \text { air } \\
\text { pada suhu } 100^{\circ} \mathrm{C}\end{array}$ & $\begin{array}{l}250 \mathrm{mg} / \mathrm{L} \text {, } \\
500 \mathrm{mg} / \mathrm{L} \text {, dan } \\
1000 \mathrm{mg} / \mathrm{L} \text { per hari } \\
\text { selama } 8 \text { minggu }\end{array}$ & Tikus & $\begin{array}{l}\text { Antidiabetes, } \\
\text { antihipertensi, dan } \\
\text { antioksidan }\end{array}$ & $\begin{array}{l}\text { Menurunkan kadar resistensi } \\
\text { insulin }\end{array}$ \\
\hline 8 & $\begin{array}{l}\text { Combretum } \\
\text { micranthum }\end{array}$ & Daun & $\begin{array}{l}1 \mathrm{~kg} \text { sampel kering } \\
\text { diekstraksi } 2 \text { kali } \\
\text { dengan etanol, } \\
\text { kemudian di maserasi } \\
\text { dengan etanol } 80 \% \\
\text { (v/v) selama } 24 \text { jam }\end{array}$ & $\begin{array}{l}200 \mathrm{mg} / \mathrm{kg} \text { per hari } \\
\text { selama } 6 \text { minggu }\end{array}$ & Mencit & $\begin{array}{l}\text { Antidiabetes dan } \\
\text { antioksidan }\end{array}$ & $\begin{array}{l}\text { Menurunkan pembentukan } \\
\text { glukosa hati dan } \\
\text { menurunkan kadar } \\
\text { glukosa darah }\end{array}$ \\
\hline 11 & $\begin{array}{l}\text { Gynostemma } \\
\text { pentaphyllum }\end{array}$ & Daun & $\begin{array}{l}\text { Diekstraksi } \\
\text { menggunakan air suling }\end{array}$ & $\begin{array}{l}100 \mathrm{mg} / \mathrm{kg} \text { dan } \\
300 \mathrm{mg} / \mathrm{kg} \text { perhari } \\
\text { selama } 12 \mathrm{minggu}\end{array}$ & Mencit & Antidiabetes & $\begin{array}{l}\text { Menurunkan kelebihan berat } \\
\text { badan dan resistensi insulin }\end{array}$ \\
\hline 13 & $\begin{array}{l}\text { Ampelopsis } \\
\text { grossedentata }\end{array}$ & $\begin{array}{l}\text { Daun dan } \\
\text { batang }\end{array}$ & $\begin{array}{l}\text { Diekstraksi } 3 \text { kali } \\
\text { (masing-masing } 7 \text { hari) } \\
\text { dengan } 40 \text { L etanol } 45 \% \\
\text { pada suhu ruang }\end{array}$ & $\begin{array}{l}50 \mathrm{mg} / \mathrm{kg} 1 \mathrm{kali} \\
\text { selama } 1 \text { hari }\end{array}$ & Mencit & Antidiabetes & $\begin{array}{l}\text { Menurunkan kadar glukosa } \\
\text { darah postprandial dan } \\
\text { menghambat aktivitas } \\
\alpha \text {-Glucosidase }\end{array}$ \\
\hline 14 & $\begin{array}{l}\text { Camellia } \\
\text { sinensis L. }\end{array}$ & Daun & $\begin{array}{l}28 \text { g sampel dididihkan } \\
\text { dengan air suling } 100^{\circ} \mathrm{C} \\
\text { selama } 6 \text { jam, kemudian } \\
\text { direndam dengan } 1 \mathrm{~L} \text { air } \\
\text { selama } 6 \text { jam }\end{array}$ & $\begin{array}{l}400 \mathrm{mg} / \mathrm{kg} \text { sehari } \\
1 \mathrm{kali} \text { selama } \\
84 \text { hari }\end{array}$ & Tikus & $\begin{array}{l}\text { Antidiabetes dan } \\
\text { antioksidan }\end{array}$ & $\begin{array}{l}\text { Menurunkan kadar glukosa } \\
\text { darah, serum insulin } \\
\text { level, kadar HbAlc darah, } \\
\text { hiperplasia dan ekspansi } \\
\text { islet pankreas }\end{array}$ \\
\hline
\end{tabular}


Tabel 3 Studi In Vivo Minuman Herbal Antidiabetes (Tabel Lanjutan)

\begin{tabular}{|c|c|c|c|c|c|c|c|}
\hline $\begin{array}{l}\text { No. } \\
\text { Artikel }\end{array}$ & $\begin{array}{c}\text { Nama } \\
\text { Tanaman }\end{array}$ & $\begin{array}{c}\text { Bagian yang } \\
\text { Digunakan }\end{array}$ & Ekstraksi & Dosis & Hewan Uji & Efek/ Hasil & Mekanisme \\
\hline 17 & $\begin{array}{l}\text { Aspalathus } \\
\text { linearis }\end{array}$ & Daun & $\begin{array}{l}\text { Diekstraksi } \\
\text { menggunakan air suling }\end{array}$ & $\begin{array}{l}0,3 \% \text { selama } \\
3 \text { minggu dan } 0,6 \% \\
\text { selama } 2 \text { minggu }\end{array}$ & Mencit & Antidiabetes & $\begin{array}{l}\text { Menurunkan glukosa darah } \\
\text { puasa, dan menurunkan ROS }\end{array}$ \\
\hline 18 & $\begin{array}{l}\text { Matricaria } \\
\text { chamomilla }\end{array}$ & Bunga & $\begin{array}{l}1 \mathrm{~g} \text { sampel diseduh } \\
\text { dengan } 150 \mathrm{~mL} \text { air } \\
\text { mendidih, tunggu } \\
\text { selama } 10-15 \text { menit }\end{array}$ & $\begin{array}{l}0,018 \mathrm{~g} / 150 \mathrm{~mL} \\
1 \text { kali selama } 1 \text { hari }\end{array}$ & Tikus & Antidiabetes & $\begin{array}{l}\text { Menurunkan kadar glukosa } \\
\text { darah puasa }\end{array}$ \\
\hline 20 & $\begin{array}{l}\text { Aspalathus } \\
\text { linearis }\end{array}$ & Daun & $\begin{array}{l}\text { Diekstraksi } \\
\text { menggunakan air suling }\end{array}$ & $\begin{array}{l}1 \mathrm{dan} 10 \mu \mathrm{g} / \mathrm{mL} \\
1 \mathrm{kali} \text { dalam } 6 \text { jam }\end{array}$ & Tikus & $\begin{array}{l}\text { Antidiabetes dan } \\
\text { antioksidan }\end{array}$ & Menurunkan ROS \\
\hline 22 & $\begin{array}{l}\text { Cyclocarya } \\
\text { paliurus }\end{array}$ & Daun & $\begin{array}{l}2,5 \mathrm{~kg} \text { sampel } \\
\text { diekstraksi dengan } \\
\text { ethanol } 80 \% \text { dan air } \\
\text { suling }(3 \times 20 \mathrm{~L} \text {, } \\
\text { setiap } 2 \text { jam })\end{array}$ & $\begin{array}{l}8 \mathrm{~g} / \mathrm{kg} \text { sekali } \\
\text { perhari selama } \\
4 \text { minggu }\end{array}$ & Tikus & $\begin{array}{l}\text { Antihiperglikemia, } \\
\text { antihiperlipidemia, } \\
\text { dan antioksidan }\end{array}$ & $\begin{array}{l}\text { Menurunkan kadar FFA, TC, } \\
\text { TG, MDA, BUN, kreatinin, } \\
\text { dan GSP }\end{array}$ \\
\hline 25 & $\begin{array}{l}\text { Diospyros } \\
\text { kaki }\end{array}$ & Daun & $\begin{array}{l}\text { Diekstraksi } \\
\text { menggunakan air suling }\end{array}$ & $\begin{array}{l}5 \mathrm{~g} / 100 \mathrm{~g} \text { per hari } \\
\text { selama } 5 \text { minggu }\end{array}$ & Mencit & $\begin{array}{l}\text { Antihiperglikemia } \\
\text { dan antidislipidemia }\end{array}$ & $\begin{array}{l}\text { Perubahan ekpresi mRNA } \\
\text { dari enzim hepatic yang } \\
\text { terlibat dalam pembentukan } \\
\text { glukosa }\end{array}$ \\
\hline 26 & $\begin{array}{l}\text { Aspalathus } \\
\text { linearis }\end{array}$ & Daun & $\begin{array}{l}\text { Sampel } 100 \mathrm{~g} \\
\text { dipanaskan dalam } \\
1000 \mathrm{~mL} \text { air murni }\end{array}$ & $\begin{array}{l}25 \mathrm{mg} / \mathrm{kg} \text { dan } \\
30 \mathrm{mg} / \mathrm{kg} \mathrm{BW} \\
1 \mathrm{kali} \text { selama } 1 \text { hari }\end{array}$ & Tikus & Antidiabetes & $\begin{array}{l}\text { Menghambat enzim } \\
\alpha \text {-Glucosidase dan } \\
\text { menurunkan kadar glukosa } \\
\text { darah puasa }\end{array}$ \\
\hline 28 & $\begin{array}{l}\text { Olea } \\
\text { europaea L. }\end{array}$ & Daun & $\begin{array}{l}\text { Sampel disoxhlet } \\
\text { dengan hexane selama } \\
3 \mathrm{~h} \text {, kemudian dengan } \\
80 \% \text { aqueous ethanol } \\
\text { selama } 6 \text { jam }\end{array}$ & $\begin{array}{l}0,1 \mathrm{~g} / 100 \mathrm{~g} \mathrm{BW} \\
1 \text { kali selama } 1 \text { hari }\end{array}$ & Tikus & Antidiabetes & $\begin{array}{l}\text { Menghambat enzim } \\
\alpha \text {-Glucosidase dan } \\
\text { menurunkan kadar glukosa } \\
\text { darah postprandial }\end{array}$ \\
\hline 29 & $\begin{array}{l}\text { Morus alba } \\
\text { L. }\end{array}$ & Daun & $\begin{array}{l}\text { Sampel diekstraksi } \\
\text { dengan etanol } 50 \%\end{array}$ & $\begin{array}{l}5 \mathrm{~g} / \mathrm{mL}, 15 \mathrm{~g} / \mathrm{mL} \\
\text { and } 45 \mathrm{~g} / \mathrm{mL} 1 \mathrm{kali} \\
\text { selama } 1 \text { hari }\end{array}$ & Tikus & Antihiperglikemia & $\begin{array}{l}\text { Memperbaiki/meningkatkan } \\
\text { penyerapan glukosa }\end{array}$ \\
\hline 30 & $\begin{array}{l}\text { Salvia } \\
\text { fruticosa }\end{array}$ & Herba & $\begin{array}{l}\text { Sampel } 2 \mathrm{~g} \text { diseduh } \\
\text { dengan } 150 \mathrm{~mL} \text { air } \\
\text { mendidih ditunggu } \\
5 \text { menit }\end{array}$ & $\begin{array}{l}0,28 \% \mathrm{w} / \mathrm{v} \text { per hari } \\
\text { selama } 14 \text { hari }\end{array}$ & Tikus & Antidiabetes & $\begin{array}{l}\text { Menurunkan kadar glukosa } \\
\text { plasma darah }\end{array}$ \\
\hline
\end{tabular}


yang diberi tanaman rooibos (Aspalathus linearis) terbukti menunjukkan aktivitas antidiabetes, yaitu dapat menekan kenaikan kadar glukosa darah puasa. ${ }^{27}$ Pada mencit yang diberikan ekstrak daun persimmon, menunjukkan bahwa ekstrak dapat menekan peningkatan kadar glukosa darah puasa mencit dari minggu ke-3 hingga minggu ke-5 dalam rentang $\pm 22,5-30 \mathrm{mmol} / \mathrm{L} .{ }^{28}$

Dari total 9 artikel yang menggunakan hewanujitikus, sebanyak 2 artikelmenjelaskan bahwa tikus diinduksi dengan HFD hingga tikus diabetes. Kemudian, tikus dibagi ke dalam 2 kelompok, yaitu kelompok kontrol (pioglitazone) dan kelompok perlakuan (Coreopsis tinctoria). Hasil dari penelitian tersebut menunjukkan bahwa ekstrak mampu menurunkan resistensi insulin. ${ }^{29}$ Selanjutnya, terdapat jenis tanaman teh hijau yang dapat menurunkan kadar glukosa darah, serum insulin, kadar $\mathrm{HbA1c}$ darah, hiperplasia serta ekspansi islet pankreas. ${ }^{30}$ Sebanyak 1 artikel menjelaskan tikus yang diinduksi dengan menggunakan alloxan monohydrate dan larutan glukosa hingga tikus diabetes, kemudian dibagi menjadi kelompok kontrol (air), kelompok perlakuan (teh chamomile), dan kelompok standar (glibenklamid). Hasil menunjukkan bahwa teh chamomile efeknya hampir mirip dengan glibenklamid sehingga konsumsi secara harian dapat berpotensi berguna dalam hiperglikemia. ${ }^{31}$ Sebanyak 6 artikel menggunakan tikus yang diinduksi dengan STZ dan diet tinggi protein hingga tikus diabetes. Hasil menunjukkan tikus yang diberi ekstrak rooibos dapat menurunkan Reactive Oxygen Species (ROS), ${ }^{32}$ dan telah terbukti lebih efektif dalam menurunkan kadar glukosa darah puasa jika dibandingkan dengan Vildagliptin. ${ }^{33}$ Tikus yang diberikan ekstrak tanaman Cyclocarya paliurus telah terbukti dapat menurunkan trigliserida (TG), MDA, blood urea nitrogen (BUN), kreatinin, dan GSP. ${ }^{34}$ Tikus yang diberikan ekstrak daun zaitun (Olea europaea L.) dapat menurunkan kadar glukosa darah postprandial. ${ }^{35}$ Tikus yang diberikan ekstrak tanaman mulberry terbukti dapat memperbaiki penyerapan glukosa sebesar $31 \pm 8,54 \pm 13$, dan $38 \pm 8 \%$. $^{36}$ Ekstrak tanaman sage (Salvia fruticosa) terbukti dapat menurunkan kadar glukosa plasma darah tikus diabetes. ${ }^{37}$

Terdapat 1 artikel yang menjelaskan penggunaan hewan uji larva Zebrafish. Larva Zebrafish (Danio rerio) merupakan organisme yang komplek, jalur metabolisme maupun reaksi fisiologis sudah lengkap dan berfungsi sehingga dapat digunakan untuk uji toksisitas serta metabolisme. Menurut regulasi etik internasional, larva ikan zebra yang berumur lima hari sesudah fertilisasi (five days postfertilization/5 dpf) disamakan dengan uji in vivo dan diterima sebagai alternatif hewan coba. ${ }^{38}$ Larva Zebrafish telah menjadi model hewan vertebrata untuk berbagai penyakit dan telah berkontribusi pada penemuan obat berbasis fenotip. ${ }^{39}$ Selain itu, Zebrafish memiliki beberapa keunggulan antara lain murah, mudah dalam perawatan, kemampuan reproduksi yang tinggi, dan sensitif terhadap senyawa xenobiotic. ${ }^{40}$ Berdasarkan studi, ekstrak tanaman mallow (Malva verticillata) yang diberikan pada larva zebrafish terbukti mampu memulihkan kerusakan alloxan pada sel islet pankreas. ${ }^{41}$

Hasil studi yang didapat berdasarkan uji praklinik menunjukkan bahwa tanaman herbal memiliki aktivitas antidiabetes dengan beberapa mekanisme, di antaranya yaitu pada tanaman daun jambu, ${ }^{23}$ Ampelopsis grossedentata, ${ }^{24}$ Combretum micranthum, ${ }^{25}$ daun teh hijau, ${ }^{30}$ rooibos (Aspalathus linearis), ${ }^{27}$ bunga chamomile, ${ }^{31}$ daun zaitun, ${ }^{35}$ dan daun sage $^{37}$ dapat menurunkan kadar glukosa darah puasa. Kemudian, pada tanaman Malva verticillata dapat memulihkan kerusakan alloxan pada sel islet pankreas. ${ }^{41}$ Tanaman Coreopsis tinctoria dan Cyclocarya paliurus dapat menurunkan kadar hepatic TG dan kolesterol total (TC). ${ }^{29,34}$ 
Studi Klinik Minuman Herbal Antidiabetes

Tabel 4 menunjukkan 2 artikel mengenai studi klinik minuman herbal antidiabetes. Menurut World Health Organization (WHO), studi klinis adalah studi penelitian yang secara prospektif menugaskan peserta atau kelompok manusia ke dalam satu atau lebih intervensi yang berhubungan dengan bidang kesehatan untuk mengevaluasi efek pada hasil intervensi perlakuan.

Pada artikel yang pertama, metode pengambilan sampel yang digunakan adalah purposive sampling. Subjek penelitian adalah wanita berusia 30-60 tahun dengan lingkar perut minimal $80 \mathrm{~cm}$ dan atau indeks massa tubuh (BMI) lebih atau sama dengan 23, glukosa darah puasa 100-125 $\mathrm{mg} / \mathrm{dL}$ berdasarkan tes cepat (glukometer) dan laboratorium analisis, dalam kesehatan yang baik, tidak menjalani program diet, tidak merokok atau mengkonsumsi alkohol, dan tidak mengonsumsi teh rosella secara teratur selama minimal tiga bulan. Setelah melalui skrining, diperoleh partisipan inklusi berjumlah 24 orang. Kemudian dilakukan perlakuan yaitu partisipan diberikan teh rosella (5 g bubuk rosella $+125 \mathrm{mg}$ stevia diseduh dalam $250 \mathrm{~mL}$ air mendidih selama 5 menit) 2 kali sehari selama 14 hari. Didapat hasil bahwa peserta mengalami penurunan signifikan dalam hal glukosa darah yaitu dari $111,25 \pm 7,20 \mathrm{mg} / \mathrm{dL}$ menjadi 88,58 $\pm 13,19$ $\mathrm{mg} / \mathrm{dL}$. Keterbatasan dalam penelitian ini terletak pada sedikitnya jumlah responden yang bersedia dilibatkan. Subjek penelitian adalah masyarakat biasa yang diambil dari skrining populasi dan belum terdiagnosis diabetes, sehingga diperlukan upaya ekstra untuk menemukan dan merekrut responden penelitian. Namun, kelebihan dari penelitian ini menunjukkan bahwa teh Rosella dan Stevia memiliki efek sebagai antidiabetik dengan menurunkan kadar glukosa darah puasa. ${ }^{42}$

Pada penelitian kedua, dilakukan intervensi dalam satu hari terhadap 30 partisipan dewasa yang tidak memiliki diabetes, 15 partisipan sebagai kelompok kontrol dan 15 partisipan

Tabel 4 Studi Klinik Minuman Herbal Antidiabetes

\begin{tabular}{|c|c|c|c|c|c|c|c|}
\hline $\begin{array}{c}\text { No. } \\
\text { Artikel }\end{array}$ & $\begin{array}{c}\text { Nama } \\
\text { Tanaman }\end{array}$ & $\begin{array}{c}\text { Bagian } \\
\text { yang } \\
\text { Digunakan }\end{array}$ & Ekstraksi & Dosis & $\begin{array}{l}\text { Jumlah } \\
\text { Subjek }\end{array}$ & Efek/Hasil & Mekanisme \\
\hline 10 & $\begin{array}{l}\text { Hibiscuss } \\
\text { sabdariffa, } \\
\text { L., Stevia } \\
\text { rebaudiana } \\
\text { Bertoni }\end{array}$ & $\begin{array}{l}\text { Bunga dan } \\
\text { daun }\end{array}$ & $\begin{array}{l}5 \mathrm{~g} \text { bubuk } \\
\text { rosella }+ \\
125 \mathrm{mg} \text { stevia } \\
\text { diseduh } \\
\text { dalam } 250 \mathrm{~mL} \\
\text { air mendidih } \\
\text { selama } \\
5 \text { menit }\end{array}$ & $\begin{array}{l}5,125 \mathrm{~g} / \\
250 \mathrm{~mL} \\
2 \text { kali } \\
\text { sehari } \\
\text { selama } \\
14 \text { hari }\end{array}$ & 24 orang & Antidiabetes & $\begin{array}{l}\text { Menurunkan } \\
\text { kadar } \\
\text { glukosa } \\
\text { darah puasa }\end{array}$ \\
\hline 16 & $\begin{array}{l}\text { Cinnamomum } \\
\text { burmannii }\end{array}$ & Korteks & $\begin{array}{l}60 \text { g sampel } \\
\text { direndam } \\
\text { dengan } 1000 \\
\text { mL air selama } \\
24 \text { jam pada } \\
\text { suhu ruang, } \\
\text { kemudian } \\
\text { dipanaskan } \\
\text { selama } 30 \\
\text { menit pada } \\
\text { suhu } 100^{\circ} \mathrm{C}\end{array}$ & $\begin{array}{l}6 \mathrm{~g} / \\
100 \mathrm{~mL} \\
1 \mathrm{kali} \\
\text { selama } \\
1 \text { hari }\end{array}$ & 30 orang & $\begin{array}{l}\text { Antidiabetes } \\
\text { dan } \\
\text { antioksidan }\end{array}$ & $\begin{array}{l}\text { Menurunkan } \\
\text { aktivitas } \\
\text { glikosidase } \\
\text { intestinal dan } \\
\text { menurunkan } \\
\text { kadar } \\
\text { glukosa } \\
\text { darah } \\
\text { postprandial }\end{array}$ \\
\hline
\end{tabular}


lainnya diberikan teh kayu manis (Cinnamon) (diseduh sebanyak 6 gr Cinnamon dalam 100 $\mathrm{mL}$ air mendidih). Para peserta diminta untuk tidak mengonsumsi makanan atau minuman dengan bahan kayu manis sehari sebelum intervensi. Pada kelompok kontrol, partisipan diberikan larutan glukosa (75 g dextrose/ $200 \mathrm{~mL}$ air) saja. Pada kelompok intervensi, setelah partisipan diberikan larutan glukosa (200 mL), partisipan langsung diminta untuk meminum $100 \mathrm{~mL}$ teh Cinnamon. Sampel darah dikumpulkan, untuk setiap peserta, pada menit 30 (t30), 60 (t60), 90 (t90), dan 120 (t120). Data hasil menunjukkan bahwa teh Cinnamon dapat lebih menurunkan kadar glukosa darah postprandial pada partisipan dibandingkan pada kelompok kontrol, yaitu dengan hasil akhir kadar glukosa darah menjadi $5,86( \pm 0,2) \mathrm{mmol} / \mathrm{L}$ pada kelompok teh Cinnamon, dan 6,40 $( \pm 0.2) \mathrm{mmol} / \mathrm{L}$ pada kelompok kontrol. ${ }^{43}$

\section{Simpulan}

Artikel review ini memberikan gambaran secara ilmiah tentang 35 jenis tanaman herbal yang sudah terbukti memiliki aktivitas antidiabetes di seluruh dunia. Bagian morfologi tanaman yang paling sering digunakan yaitu bagian daun. Mekanisme in vitro dari tanaman herbal dalam memberikan aktivitas antidiabetes yaitu dengan menghambat aktivitas enzim $\alpha$-Amylase dan $\alpha$-Glucosidase. Pada uji in vivo dan uji klinik, semua tanaman herbal yang digunakan dalam penelitian mempunyai aktivitas menurunkan kadar glukosa darah sehingga dapat dimanfaatkan sebagai minuman obat herbal. Berdasarkan berbagai penelitian yang telah dilakukan dan hasil yang telah didapat, penulis menyarankan bahwa dalam penelitian selanjutnya, perlu dilakukan penelitian tentang toksisitas dan potensi efek samping penggunaan dari setiap bahan-bahan herbal yang digunakan sebagai minuman kesehatan antidiabetes.

\section{Pendanaan}

Penulis tidak memperoleh dana dari sumber manapun dalam penelitian, penulisan, dan atau publikasi artikel ini.

\section{Konflik Kepentingan}

Seluruh penulis menyatakan tidak terdapat konflik kepentingan dalam penulisan artikel ini.

\section{Daftar Pustaka}

1. World Health Organization. Global report on diabetes. Geneva: World Health Organization: WHO Press.

2. International Diabetes Federation. IDF diabetes atlas, $6^{\text {th }}$ Edition. Brussels, Belgium: International Diabetes Federation; 2013.

3. de Lima ME, Colpo AZC, Rosa H, Salgueiro ACF, da Silva MP, Noronha DS, et al. Ilex paraguariensis extracts reduce blood glucose, peripheral neuropathy and oxidative damage in male mice exposed to streptozotocin. J Funct Foods. 2018;44(May):9-16. doi: 10.1016/j.jff.20 18.02.024

4. Amarowicz R, Shahidi F. Antioxidant activity of broad bean seed extract and its phenolic composition. J Funct Foods. 2017;38(November):656-62. doi: 10.101 6/j.jff.2017.04.002

5. Granato D, Shahidi F, Wrolstad R, Kilmartin P, Melton LD, Hidalgo FJ, et al. Antioxidant activity, total phenolics and flavonoids contents: Should we ban in vitro screening methods?. Food Chem. 2018;264:471-5. doi: 10.1016/j.foodchem. 2018.04.01

6. Chandrasekara A, Shahidi F. Herbal beverages: Bioactive compounds and their role in disease risk reduction. $\mathrm{J}$ Tradit Complement Med. 2018;8(4):451- 
8. doi: 10.1016/j.jtcme.2017.08.006

7. Perera PRD, Ekanayake S, Ranaweera KKDS. Antidiabetic compounds in Syzygium cumini decoction and ready to serve herbal drink. Evid Based Complement Altern Med. 2017;2017:1083589. doi: 10. 1155/2017/1083589

8. Munadi E, Salim Z. Info komoditi obat. Jakarta: Badan Pengkajian dan Pengembangan Perdagangan Kementerian Perdagangan Republik Indonesia; 2017.

9. Tunev SS, Hastey CJ, Hodzic E, Feng S, Barthold SW, Baumgarth N. Lymphoadenopathy during lyme borreliosis is caused by spirochete migration-induced specific B cell activation. PLoS Pathog. 2011;7(5):1-14. doi: 10.1371/journal.ppa t. 1002066

10. Eruygur N, Dural E. Determination of 1-Deoxynojirimycin by a developed and validated HPLC-FLD method and assessment of in-vitro antioxidant, $\alpha$-Amylase and $\alpha$-Glucosidase inhibitory activity in mulberry varieties from Turkey. Phytomedicine. 2019;53(February): 23442. doi: 10.1016/j.phymed.2018.09.016

11. Meng Y, Ding L, Wang Y, Nie Q ting, Xing $\mathrm{Y}$ yang, Ren Q. Phytochemical identification of Lithocarpus polystachyus extracts by ultra-high-performance liquid chromatography-quadrupole time-offlight-MS and their protein tyrosine phosphatase 1B and $\alpha$-glucosidase activities. Biomed Chromatogr. 2020;34 (1):e4705. doi: 10.1002/bmc.4705

12. Gremski LA, Coelho ALK, Santos JS, Daguer H, Molognoni L, do Prado-Silva L, et al. Antioxidants-rich ice cream containing herbal extracts and fructooligossaccharides: Manufacture, functional and sensory properties. Food Chem. 2019;298:125098. doi: 10.1016/j.food chem.2019.125098

13. Villa-Rodriguez JA, Aydin E, Gauer JS, Pyner A, Williamson G, Kerimi A. Green and chamomile teas, but not acarbose, attenuate glucose and fructose transport via inhibition of GLUT2 and GLUT5. Mol Nutr Food Res. 2017;61(12):1-47. doi: 10.1002/mnfr.201700566

14. Ma YY, Zhao DG, Zhou AY, Zhang Y, Du Z, Zhang K. $\alpha$-Glucosidase inhibition and antihyperglycemic activity of phenolics from the flowers of edgeworthia gardneri. J Agric Food Chem. 2015;63(37):8162-9. doi: 10.1021/acs.jafc.5b03081

15. Oboh G, Ogunruku OO, Ogidiolu FO, Ademiluyi AO, Adedayo BC, Ademosun AO. Interaction of some commercial teas with some carbohydrate metabolizing enzymes linked with type- 2 diabetes: A dietary intervention in the prevention of type-2 diabetes. Adv Prev Med. 2014; 2014:534082 doi: 10.1155/2014/534082

16. Dalar A, Türker M, Zabaras D, Konczak I. Phenolic composition, antioxidant and enzyme inhibitory activities of Eryngium bornmuelleri leaf. Plant Foods Hum Nutr. 2014;69(1):30-6. doi: 10.1007/s11130-0 13-0393-6

17. Wang L, Luo Y, Wu Y, Liu Y, Wu Z. Fermentation and complex enzyme hydrolysis for improving the total soluble phenolic contents, flavonoid aglycones contents and bio-activities of guava leaves tea. Food Chemistry. 2018;264:189-98. doi: 10.1016/j.foodchem.2018.05.035

18. Pereira CG, Barreira L, Bijttebier S, Pieters L, Marques C, Santos TF, et al. Health promoting potential of herbal teas and tinctures from Artemisia campestris subsp. maritima: From traditional remedies to prospective products. Sci Rep. 2018;8(1):4689. doi: 10.1038/s41598-01 8-23038-6

19. Oliveira AP, Matos RP, Silva ST, Andrade PB, Ferreres F, Gil-Izquierdo $A$, et al. A new iced tea base herbal beverage with Spergularia rubra extract: Metabolic profile stability and in vitro enzyme inhibition. J Agric Food Chem. 
2013;61(36):8650-6. doi: 10.1021/jf401 $884 \mathrm{u}$

20. Chen YG, Li P, Li P, Yan R, Zhang XQ, Wang $Y$, et al. $\alpha$-glucosidase inhibitory effect and simultaneous quantification of three major flavonoid glycosides in microctis folium. Molecules. 2013;8:4221 -32. doi: 10.3390/molecules18044221

21. Nyirenda KK, Saka JDK, Naidoo D, Maharaj VJ, Muller CJF. Antidiabetic, anti-oxidant and antimicrobial activities of Fadogia ancylantha extracts from Malawi. J Ethnopharmacol. 2012;143(1):372-6. doi: 10.1016/j.jep.2012.07.002

22. Huang W, Percie du Sert N, Vollert J, Rice ASC. General principles of preclinical study design. In: Bespalov A, Michel MC. (eds) Good research practice in nonclinical pharmacology and biomedicine. Handbook of experimental pharmacology, vol 257. Philadelphia: Springer, Cham; 2019.

23. Luo Y, Peng B, Wei W, Tian X, Wu Z. Antioxidant and anti-diabetic activities of polysaccharides from guava leaves. Molecules. 2019;24(7):1343. doi: 10.339 0/molecules24071343

24. Chen J, Wu Y, Zou J, Gao K. $\alpha$-Glucosidase inhibition and antihyperglycemic activity of flavonoids from Ampelopsis grossedentata and the flavonoid derivatives. Bioorg Med Chem. 2016;24(7):1488-94. doi: 10.1016 /j.bmc.2016.02.018

25. Welch C, Zhen J, Bassène E, Raskin I, Simon JE, Wu Q. Bioactive polyphenols in kinkéliba tea (Combretum micranthum) and their glucose-lowering activities. J Food Drug Anal. 2018;26(2):487-96.

26. Liu J, Li Y, Yang P, Wan J, Chang Q, Wang TTY, et al. Gypenosides Reduced the Risk of overweight and insulin resistance in $\mathrm{C} 57 \mathrm{BL} / 6 \mathrm{~J}$ mice through modulating adipose thermogenesis and gut microbiota. J Agric Food Chem. 2017;65(42):9237-46. doi: 10.1021/acs. jafc. $7 b 03382$

27. Kamakura R, Son MJ, de Beer D, Joubert E, Miura Y, Yagasaki K. Antidiabetic effect of green rooibos (Aspalathus linearis) extract in cultured cells and type 2 diabetic model KK-Ay mice. Cytotechnology. 2015;67(4):699-710. doi: 10.1007/s10616 -014-9816-y

28. Jung UJ, Park YB, Kim SR, Choi MS. Supplementation of persimmon leaf ameliorates hyperglycemia, dyslipidemia and hepatic fat accumulation in type 2 diabetic mice. PLoS One. 2012;7(11): e49030. doi: 10.1371/journal.pone.00490 30

29. Jiang B, Lv Q, Wan W, Le L, Xu L, Hu $\mathrm{K}$, et al. Transcriptome analysis reveals the mechanism of the effect of flower tea: Coreopsis tinctoria on hepatic insulin resistance. Food Funct. 2018;9(11):560720. doi: $10.1039 / \mathrm{c} 8$ fo00965a

30. Lee JE, Kang SJ, Choi SH, Song CH, Lee YJ, Ku SK. Fermentation of green tea with $2 \%$ Aquilariae lignum increases the anti-diabetic activity of green tea aqueous extracts in the high fat-fed mouse. Nutrients. 2015;7(11):9046-78. doi: 10.33 90/nu7115447

31. Khan SS, Najam R, Anser H, Riaz B, Alam N. Chamomile tea: Herbal hypoglycemic alternative for conventional medicine. Pak J Pharm Sci. 2014;27(5):1509-14.

32. Dludla P V., Muller CJF, Louw J, Joubert E, Salie R, Opoku AR, et al. The cardioprotective effect of an aqueous extract of fermented rooibos (Aspalathus linearis) on cultured cardiomyocytes derived from diabetic rats. Phytomedicine. 2014;21(5):595-601. doi: 10.1016/j.phy med.2013.10.029

33. Muller CJF, Joubert E, de Beer D, Sanderson M, Malherbe CJ, Fey SJ, et al. Acute assessment of an aspalathinenriched green rooibos (Aspalathus linearis) extract with hypoglycemic 
potential. Phytomedicine. 2012;20(1):329. doi: 10.1016/j.phymed.2012.09.010

34. Wang Q, Jiang C, Fang S, Wang J, Ji Y, Shang X, et al. Antihyperglycemic, antihyperlipidemic and antioxidant effects of ethanol and aqueous extracts of Cyclocarya paliurus leaves in type 2 diabetic rats. J Ethnopharmacol. 2013; 150(3):1119-27. doi: 10.1016/j.jep.2013. 10.040

35. Wainstein J, Ganz T, Boaz M, Bar Dayan Y, Dolev E, Kerem Z, et al. Olive leaf extract as a hypoglycemic agent in both human diabetic subjects and in rats. J Med Food. 2012;15(7):605-10. doi: 10.1089/ jmf.2011.0243

36. Naowaboot J, Pannangpetch P, Kukongviriyapan V, Prawan A, Kukongviriyapan U, Itharat A. Mulberry leaf extract stimulates glucose uptake and GLUT4 translocation in rat adipocytes. Am J Chin Med. 2012;40(1):163-75. doi: 10.1142/S0192415X12500139

37. Azevedo MF, Lima CF, FernandesFerreira M, Almeida MJ, Wilson JM, Pereira-Wilson C. Rosmarinic acid, major phenolic constituent of Greek sage herbal tea, modulates rat intestinal SGLT1 levels with effects on blood glucose. Mol Nutr Food Res. 2011;55(1):15-25. doi: 10.1002/mnfr.201000472

38. European Parliament and Council of the European Union. Directive 2010/63/EU of the European Parliament and of the
Council of 22 September 2010 on the protection of animals used for scientific purposes. Official J European Union; 2013.

39. Stewart AM, Cachat J, Green J, Gaikwad S, Kyzar E, Roth A, et al. Constructing the habituome for phenotype-driven zebrafish research. Behav Brain Res. 2013; 236(1):110-7. doi: 10.1016/j.bbr.2012.08 .026

40. Velki M, Meyer-Alert H, Seiler TB, Hollert H. Enzymatic activity and gene expression changes in zebrafish embryos and larvae exposed to pesticides diazinon and diuron. Aquat Toxicol. 2017;193:187200. doi: 10.1016/j.aquatox.2017.10.019

41. Ko JH, Rodriguez I, Joo SW, Kim HG, Lee YG, Kang TH, et al. Synergistic effect of two major components of Malva verticillata in the recovery of alloxan-damaged pancreatic islet cells in zebrafish. J Med Food. 2019;22(2):196201.

42. Mayasari NR, Susetyowati, Wahyuningsih MSH, Probosuseno. Antidiabetic effect of rosella-stevia tea on prediabetic women in Yogyakarta, Indonesia. J Am Coll Nutr. 2018;37(5):373-9. doi: 10.1080/0731572 4.2017.1400927

43. Bernardo MA, Silva ML, Santos E, Moncada MM, Brito J, Proença L, et al. Effect of cinnamon tea on postprandial glucose concentration. J Diabetes Res. 2015;2015:913651. doi: 10.1155/2015/91 3651 